\title{
ISYARAT SOSIAL EKONOMI DALAM PEMBENTUKAN ENTITAS AGRIBISNIS KEMITRAAN PADA STRUKTUR SOSIAL KEMASYARAKATAN HETEROGEN
}

\author{
Sosial Economic Cues of Agribusiness Partnership Entities in Heterogeneous of Community Social Structure \\ Serly Novita Sari, Fachrurrozie Sjarkowi, Mirza Antoni \\ Sekolah Tinggi Ilmu Pertanian Belitang \\ Jln.Kampus Pertanian No.3 Belitang Kab.OKU Timur Prov.Sumatera Selatan \\ e-mail: Serlynovitasari282@yahoo.co.id
}

\begin{abstract}
The objectives of this research are to: 1) identify the farmer's total income of pre-plasma in establishing agribusiness partnership entity, 2) Identify the conditions of peasant social capital as supporting efforts to establish a partnership of agribusiness entity, 3) analyze the comparation of total income between pre-plasma farmer's income and post-plasma income expectation in establishing agribusiness partnership entity, 4) Identify the response of the community in establishing partnerships agribusiness entities. The research result showed that income of farmer's are relatively low. The conditions of peasant social capital in the village of Karang Endah and Tanjung Agung quite adequate. Farmer's income of pre-plasma (slab) is smaller than the farmers' income expectations of post-plasma (palm oil). The response of the community in establishing agribusiness partnership entity in the village of Karang Endah and Tanjung Agung was agreed, it means agribusiness investment partnerships will be easily occurred. Based on the results of those research in the village of Karang Endah and Tanjung Agung, we can conclude that Ho points 0.1 was accepted. It means if the farmer's rubber income of pre-plasma is smaller than the income of farmer's expectations of post-plasma and the conditions social capital is adequate, so the establishment of agribusiness entities will be easily occurred.
\end{abstract}

Key Word : Socio-economic, Social Capital, Agribusiness Partnership

\section{PENDAHULUAN}

\section{A. Latar Belakang}

Saat ini investasi agribisnis kemitraan adalah salah satu investasi yang sangat diminati oleh para calon investor. Hal ini dikarenakan komoditi yang diusahakan dalam investasi agribisnis kemitraan adalah salah satu dari sedikit industri yang komoditinya merupakan keunggulan kompetitif Indonesia untuk bersaing ditingkat global (Pahan, 2008). Maraknya investasi agribisnis kemitraan semakin tahun semakin ekspansif dan meluas. Pada umumnya dalam setiap kegiatan investasi, lahan merupakan aset yang terpenting dan alat produksi yang paling vital. Sehingga dapat dipastikan bahwa dalam setiap kegiatan investasi dalam berbagai sektor, konflik lahan menduduki peringkat paling atas (Frasetiandy, 2009).

Jika ditinjau dari perspektif satuan investasi, maka ada dua kemungkinan yang akan terjadi yakni investasi agribisnis kemitraan dapat terjadi lancar dan investasi agribisnis kemitraan akan menjadi terhambat. Hal ini disebabkan sinergi dalam menaklukkan kendala dan hambatan di suatu wilayah investasi tidak mudah terbina bagi keberhasilan calon investor agribisnis. Sehingga dalam pembentukkan suatu entitas agribisnis kemitraan, potensi sosio-ekonomi, sosio-psikologis, dan sosio-kultural (sosekbud) harus dikendalikan. Secara sosekbud, jika potensi-potensi tersebut tidak dikendalikan, maka akan ada kecenderungan tumbuh dualisme ekonomi maju dan tradisional yang menyebabkan konflik sosial, sehingga akan menghambat keberhasilan investasi agribisnis kemitraan. Jika potensi-potensi tersebut dikendalikan, maka investasi agribisnis kemitraan akan berjalan lancar dan sistemik. Akan tetapi, tentulah maksud demikian tidak akan mudah direalisasikan, jika pemerintah dan para pelaku usaha pertanian tidak menyadari adanya saling ketergantungan antar berbagai faktor alami, faktor teknis dan sosio-ekonomi wilayah sasaran investasi agribisnis kemitraan. Hal ini dikarenakan investasi agribisnis kemitraan harus dibina secara sistemik, sehingga perlu mensinergikan semua pihak yang terlibat dalam pembentukan entitas agribisnis kemitraan, dengan cara melibatkan tiga pilar utama yakni masyarakat, pemerintah dan investor yang dapat menopang satu sama lainnya sehingga investasi agribisnis kemitraan dapat berjalan dengan lancar. Hal ini jelas diperlukan langkah-langkah strategis dan taktik agar tercapainya sinergi antara masyarakat, pemerintah dan investor, yakni dengan mengetahui faktor-faktor sosekbud di wilayah sasaran investasi agribisnis kemitraan. Sehingga potensi-potensi konflik sosial yang ada di daerah setempat dapat dikendalikan, dan akhirnya investasi agribisnis kemitraan akan terealisasikan (Sjarkowi, 2010). Hal-hal seperti inilah yang harus menjadi banyak pertimbangan berbagai pihak dalam pengambilan kebijakan untuk berinvestasi terutama dalam melihat kondisi masyarakat dimana akan dibukanya investasi agribisnis kemitraan, yakni dengan mengadopsi potensi yang ada di wilayah sasaran investasi agribisnis kemitraan. Ketimbang 
memaksakan suatu kebijakan yang justru akan menambah panjang daftar konflik antara masyarakat, pemerintah dan investor. Kesesuaian sosekbud menjadi sangat berarti untuk dipertimbangkan ketika disadari bahwa kebanyakan kegiatan agribisnis kemitraan akan menyentuh kehidupan pedesaan dengan keadaan masyarakatnya yang masih terbatas pendidikan dan terbatas kemampuan. Hasil kajian kesesuaian sosekbud harus menjamin keberpihakan yang wajar terhadap masyarakat atas setiap gerak perubahan sosialekonomi-budaya yang akan termotivasi oleh suatu rencana investasi agribisnis kemitraan, sehingga investasi agribisnis kemitraan pun dapat terealisasiakan secara lancar.

Berdasarkan isu-isu yang sering terjadi dalam investasi agribisnis kemitraan, maka peneliti tertarik untuk melakukan kajian sosial-ekonomi yang dapat menjadi dasar pemicu terbentuknya entitas agribisnis kemitraan. Secara diagramatis adapun latar belakang dari penelitidan ini dapat dilihat pada Gambar 1.

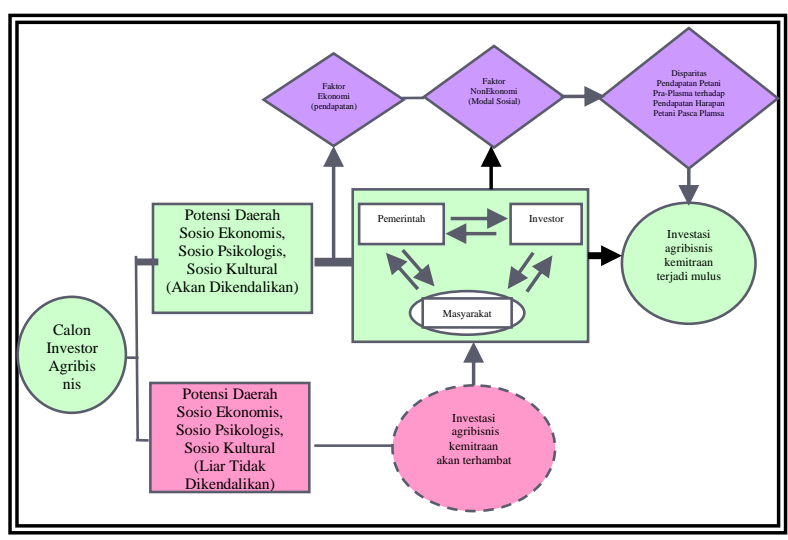

\section{B. Rumusan Masalah}

Berdasarkan penelitian terdahulu, isyarat sosioekonomi untuk menonjolkan potensi di suatu daerah dapat dikaji melalui faktor ekonomi (Zaelani, 2008) dan faktor non ekonomi (Wirawan, 2003 dalam Yulianis dan Harfiati, 2008) yang ada di masingmasing daerah. Faktor ekonomi terkait dengan variasi jenis dan sifat komoditi pertanian yang tidak tahan lama membuat harga komoditi menjadi rendah. Tingginya harga sarana produksi komoditas pertanian, adanya indikasi over produksi, harga produk pertanian yang mengalami fluktuasi dalam jangka pendek, dan lemahnya permodalan petani. Maka kondisi seperti inilah yang berpengaruh pada rendahnya pendapatan, dengan keadaan demikian maka masyarakat akan mudah untuk diajak bermitra. Hal ini dikarenakan masyarakat mengharapkan pendapatan yang lebih besar daripada pendapatan sebelumnya untuk memenuhi kebutuhan hidupnya (Mardikanto, 2009).

Faktor non-ekonomi terkait dengan konsep modal sosial yang diartikan sebagai aspek dari hubungan antara individu yang memungkinkan mereka menciptakan nilai-nilai baru (Coleman 1988, dalam Yulianis dan Harfiati, 2008) Keberadaan modal sosial akan meningkatkan kemampuan para aktor kemitraan dalam membina institusi yang menjadi acuan dalam bertindak, sehingga agribisnis kemitraan menjadi sebuah institusi yang solid dan harmonis (Fadjar, 2006 dalam Yulianis dan Harfiati, 2008) .

Berdasarkan latar belakang dan uraian di atas, adapun permasalahan yang menarik untuk diteliti adalah sebagai berikut :

1. Bagaimana keadaan sosio-ekonomi masyarakat dalam pembentukan entitas agribisnis kemitraan?

2. Bagaimana keaadan modal soial masyarakat dalam pembentukan entitas agribisnis kemitraan?

3. Berapa besar disparitas pendapatan usahatani petani pra plasma dengan pendapatan harapan petani pasca-plasma?

\section{Tujuan dan Kegunaan}

Berdasarkan rumusan masalah yang telah dijabarkan, maka secara umum penelitian ini bertujuan untuk menganalisis isyarat sosio-ekonomi dalam pembentukan entitas agribisnis kemitraan dan secara khususnya penelitian ini bertujuan untuk :

1. Mengidentifikasi faktor ekonomi yang dilihat dari struktur pendapatan total petani pra-plasma.

2. Mengidentifikasi faktor non-ekonomi (partisipasi dalam suatu jariangan, reseprositas, kepercayaa, dan norma sosial) sebagai upaya penunjang dalam pembentukan entitas agribisnis kemitraan.

3. Menghitung potensi peningkatan pendapatan petani pasca plasma dalam kegiatan agribisnis kemitraan.

Hasil penelitian ini diharapkan menjadi bahan informasi dan manfaat bagi pihak-pihak berkepentingan dalam pembentukan entitas agribisnis kemitraan dalam pengembangan dan pembangunan pertanian berkelanjutan yang berbasis ekonomi kerakyatan guna meningkatkan kesejahteraan petani. Selain itu, hasil ini juga diharapkan dapat memberi instrumen kepada peneliti selajutnya karena relevan terhadap kebutuhan pasar.

\section{KERANGKA PEMIKIRAN}

\section{A. Model Pendekatan}

Berdasarkan kajian kepustakaan tersimpul bahwa dalam rangka membentuk suatu entitas agribisnis kemitraan, maka kajian sosio-ekonomi perlu membahas dimensi ekonomi (Zaelani, 2008) dan non ekonomi (Wirawan, 2003 dalam Yulianis dan Harfiati, 2008). Dimensi ekonomi tentu erat kaitannya dengan isu pendapatan potensial yang akan didapatkan oleh calon-calon petani mitra seandainya kemitraan itu terjadi. Seterusnya, dimensi non-ekonomi akan terkait dengan isu modal sosial sebagai penunjang upayaupaya meraih suatu tingkat pendapatan yang diidamkan.

Pendapatan dapat dipengaruhi oleh harga produksi dan produk yang dihasilkan. Pendapatan yang rendah akan menganggu semangat petani untuk berproduksi. Sebagai akibat rendahnya pendapatan 
sekarang, dalam keaadaan yang paling ekstrim petani akan meninggalkan atau merubah usahanya ke bentuk usaha lain sehingga petani lebih mudah untuk diajak bermitra. Sebaliknya pendapatan petani yang tinggi sekarang akan merangsang petani untuk berproduksi dan mengelola usahataninya secara maksimal yang menyebabkan petani sulit dalam membentuk kemitraan (Mubyarto, 1989 dalam Asim, 2001). Terkait dengan akuntansi perhitungan besaran pendapatan, tentunya tingginya biaya produksi, harga jual yang rendah dan pemasaran yang tidak pasti akan mempengaruhi tingkat produktivitas yang mendasari pendapatan petani (Winardi, 1992 dalam Yulianis dan Harfiati, 2008). Pendapatan petani dapat diatasi melalui kemitraan usaha antara petani dengan perusahaan. Hal ini dikarenakan, pihak mitra yaitu perusahaan memiliki beberapa keunggulan dalam hal ketersediaan sarana produksi, tersedianya teknologi budidaya serta jaminan pemasaran yang dimiliki. Keunggulan tersebut tidak dimiliki oleh petani, tetapi petani memiliki keunggulan dalam hal ketersediaan lahan, tenaga kerja, dan hasil produksi sebagai bahan baku bagi perusahaan. Bagi petani dengan adanya kerjasama kemitraan, maka biaya produksi dapat terpenuhi sehingga dapat berdampak positif terhadap pendapatan dan kesejahteraan petani (Mardikanto, 2009). Dilain pihak, turunnya permintaan dan adanya fluktuasi harga membuat pendapatan petani tidak stabil sehingga mengharuskan mereka melakukan diversifikasi pendapatan. Semakin beragam kegiatan usahatani yang dilakukan oleh petani maka semakin besar juga pendapatan yang diterimanya (Mubyarto, 1989 dalam Asim, 2001).

Dimensi telaah modal sosial terletak pada kemampuan masyarakat dalam bekerja sama membangun suatu jaringan untuk mencapai tujuan bersama (Hasbullah, 2006 dalam Ramadona, 2010). Menurut Ridell (1997) dalam Yulianis dan Harfiati (2008), tiga parameter modal sosial yakni kepercayaan (trust), norma-norma (norms), dan partisipasi dalam suatu jaringan (network) dan ditambahkan oleh Hasabullah (2006) dalam Ramadona (2010), salah satu ukuran modal sosial dalam suatu masyarakat yakni hubungan timbal balik (reciprocity). Partisiasi dalam suatu jaringan merupakan kerelaan untuk ikut serta bekerjasama dalam organisasi yang ada dalam kelompok masyarakat untuk membangun sejumlah asosiasi berikut membangun jaringannya (Hasabullah, 2006 dalam Ramadona, 2010). Kepercayaan adalah sikap saling mempercayai di masyarakat. Masyarakat yang kurang memiliki perasaaan saling mempercayai akan sulit menghindari berbagai situsi kerawanan sosial dan ekonomi yang mengancam. (Robert dalam Mawardi, 2007). Norma-norma terdiri dari pemahaman-pemahaman, nilai-nilai, harapan-harapan dan tujuan-tujuan yang diyakini dan dijalankan bersama oleh sekelompok orang. Norma-norma dapat bersumber dari agama, maupun panduan moral. Norma-norma dibangun dan berkembang berdasarkan kerjasama di masa lalu dan diterapkan untuk mendukung iklim kerjasama (Putnam, 1993; Fukuyama,
1995) dalam Yulianis dan Harfiati (2008). Hubungan timbal balik yang menjadi dasar terjalinnya hubunganhubungan antar individu tanpa dilatarbelakangi rasa saling curiga. Semangat kerjasama akan mendorong integrasi sosial yang tinggi.

Arahan konseptual dan asumsi-asumsi yang terkandung dalam uraian di atas memungkinkan tersususunnya suatu kerangka berfikir argumentatif berupa model pendekatan, bagan alir ${ }^{4}$ Gambar 2 .

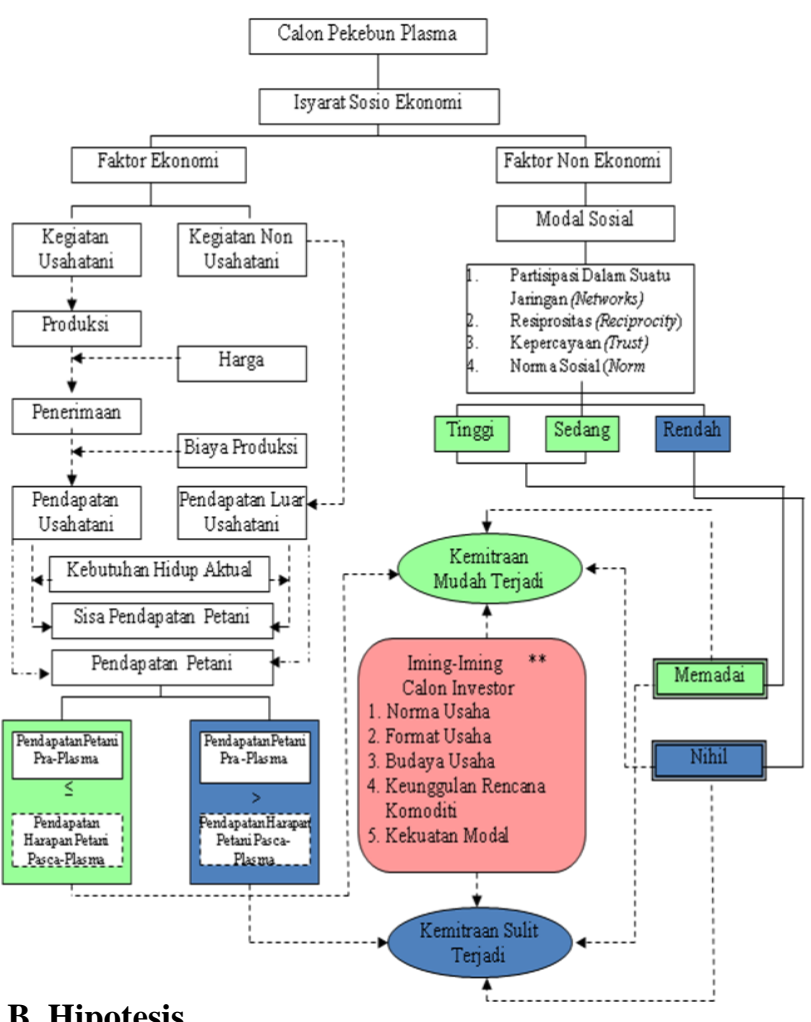

B. Hipotesis

Tampak pada model adanya empat kemungkinan kondisi sosial kemasyarakatan yang mungkin dijumpai secara empiris di lapangan, yakni :

1. Tingkat pendapatan keluarga petani sekarang diyakininya akan lebih kecil dari tingkat pendapatan yang bisa didapatnya jika memilih bermitra dengan investor, sementara komunitas masyarakatnya memiliki modal sosial memadai.

2. Tingkat pendapatan keluarga petani sekarang diyakininya akan lebih kecil dari tingkat pendapatan yang bisa didapatnya jika memilih bermitra dengan investor, sementara komunitas masyarakatnya tidak memiliki modal sosial.

3. Tingkat pendapatan keluarga petani sekarang diyakininya akan lebih besar dari tingkat pendapatan jika petani memilih bermitra dengan investor, sementara komunitas masyarakatnya tidak punya modal sosial.

4. Tingkat pendapatan keluarga petani sekarang diyakinya akan lebih besar dari tigkat pendapatan jika petani memilih bermitra dengan investor, sementara komunitas masyarakatnya mempunyai modal sosial yang memadai.

* Pendapatan harapan (expected income) petani pasca plasma, tidak diteliti diterima sebagai informasi sekunder dari calon investor

* Perbandingan pendapatan petani antara pra-plasma dan pasca-plasma, hanya dibandingkan berdasarkan pendapatan yang diperoleh dari usahatani karet, kopi, lada (pra-plasma) dan pendapatan dari usahatani kelapa sawit yang ditawarkan investor (pasca-plasma) 
Berdasarkan pola pikir konseptual teoritis yang ada pada model pendekatan, maka penelitian ini akan difokuskan untuk menguji keberlakuan empat hipotesis sebagai berikut :

$\mathrm{H}_{0}$ : Agribisnis kemitraan akan mudah terjadi

0.1.Diduga jika pendapatan usahatani petani praplasma lebih kecil daripada pendapatan harapan petani pasca plasma dan keadaan modal sosial yang dimiliki oleh petani memadai, maka pembentukan entitas agribisnis kemitraan akan mudah terjadi.

0.2.Diduga jika pendapatan usahatani petani praplasma lebih kecil daripada pendapatan harapan petani pasca plasma dan keadaan modal sosial yang dimiliki oleh petani nihil, maka pembentukan entitas agribisnis kemitraan akan mudah terjadi.

$\mathrm{H}_{1}$ : Agribisnis kemitraan akan sulit terjadi

1.1. Diduga jika pendapatan usahatani petani praplasma lebih besar daripada pendapatan harapan petani pasca plasma dan keadaan modal sosial yang dimiliki oleh petani nihil, maka pembentukan entitas agribisnis kemitraan akan sulit terjadi.

1.2. Diduga jika pendapatan usahatani petani praplasma lebih besar daripada pendapatan harapan petani pasca plasma dan keadaan modal sosial yang dimiliki oleh petani memadai, maka pembentukan entitas agribisnis kemitraan akan sulit terjadi terjadi

\section{Batasan-Batasan}

1. Pembentukan entitas agribinisnis kemitraan adalah kerjasama dalam bidang pertanian khususnya kelapa sawit yang dilakukan calon pekebun plasma dengan calon investor, yang dibantu oleh pemerintah sebagai fasilitator.

2. Calon pekebun plasma adalah petani contoh yang ada di Desa Karang Endah dan Desa Tanjung Agung Kecamatan Lengkiti Kabupaten OKU.

3. PT.Arthindo Pasific yang rencananya akan dibangun pada tahun 2010 di Kecamatan Lengkiti Kabupaten OKU diasumsikan sebagai calon investor.

4. Isyarat sosial ekonomi terdiri dari faktor ekonomi dan faktor non-ekonomi.

5. Faktor ekonomi merupakan pendapatan petani contoh (Rp/lg/thn).

6. Faktor non-ekonomi merupakan faktor sosial yang terdiri dari partisipsi dalam suatu jaringan (networks), hubungan timbal balik (resiprocity), kepercayaan (trust) dan norma sosial (norms) dari petani contoh.

7. Biaya produksi terdiri dari biaya tetap dan biaya variabel $(\mathrm{Rp} / \mathrm{lg} / \mathrm{thn})$.

8. Produksi adalah hasil yang diterima dari kegiatan usahatani satu tahun dari tanaman karet, kopi, lada, duku, dan durian (kg/lg/thn).
9. Biaya tetap terdiri dari biaya penyusutan alat-alat usahatani seperti, cangkul, arit, parang dan alatalat usahatani lainnya (Rp/lg/thn).

10. Biaya variabel seperti biaya pupuk, pestisida, dan upah tenaga kerja (Rp/lg/thn).

11. Harga jual adalah harga jual masing-masing komoditi pada saat penelitian berlangsung yakni pada bulan Desember $2010(\mathrm{Rp} / \mathrm{kg})$.

12. Penerimaan usahatani adalah jumlah produksi semua kegiatan usahatani seperti produksi karet, kopi, lada, duku, dan durian dikalikan dengan harga jual masing-masing komoditi (Rp/lg/thn).

13. Pendapatan usahatani merupakan pendapatan total dari semua kegiatan usahatani yang dilakukan oleh petani contoh seperti kegiatan usahatani karet, kopi, lada, duku dan durian (Rp/lg/thn).

14. Pendapatan non-usahatani merupakan pendapatan di luar kegiatan usahatani seperti PNS, dagang, sewa-menyewa, sopir dan buruh ( $\mathrm{Rp} / \mathrm{thn})$.

15. Struktur pendapatan petani merupakan total pendapatan dari pendapatan usahatani dan pendapatan non-usahatani (Rp/thn).

16. Pendapatan petani pra-plasma merupakan total pendapatan petani dari usahatani (tanaman karet, kopi, lada) dilakukan sebelum petani bermitra dengan investor, yang dihitung menggunakan NPV (Rp/ha/thn).

17. Pendapatan petani pasca-plasma merupakan pendapatan harapan dari usahatani kelapa sawit, seandainya petani memilih bermitra dengan investor, yang dihitung menggunakan NPV (Rp/ha/thn).

18. Modal sosial dalam hal ini terdiri dari kepercayan, resiprositas, partisipasi dalam suatu jaringan, dan norma sosial.

19. Kepercayaan dapat diukur dari tingkat kepercayaan petani terhadap sesama, tokoh masyarakat, kepala desa, aparatur pemerintah, tingkat kepercayan dan pendatang.

20. Resiprositas dapat diukur dari kemampuan petani bergotong royong membangun rumah, gotong royong dalam berusahatani, kepedulian petani untuk membantu penyelenggaraan suatu acara, jaga malam, dan membersihkan tempat ibadah

21. Partisipasi dalam suatu jaringan dapat diukur dari jumlah organisasi yang diikuti (pengajian, lembaga adat, kelompok tani, dan lainnya), frekuensi mengikuti kegiatan, kemampuan mengkordinir dalam suatu kegiatan, memberikan informasi, dan kemampuan dalam pemecahan masalah.

22. Norma sosial dapat diukur dari tingkat ketaatan terhadap aturan meminta izin untuk pertunangan dan pernikahan ke lembaga adat, tingkat ketaatan terhadap perjanjian bagi hasil antara pemilik dan penggarap, ada tidaknya sanksi bagi pelanggar norma, pengaruh orang yang dituakan terhadap pengambilan keputusan, dan tingkat ketaatan terhadap aturan pemerintah.

23. Modal sosial disebut memadai, jika modal sosial teridentifikasi tergolong tinggi dan sedang. 
24. Modal sosial disebut nihil, jika modal sosial teridentifikasi tergolong rendah.

25. Modal sosial terolong tinggi, jika memiliki skor total $46,66<\mathrm{x} \leq 60,00$.

26. Modal sosial tergolong sedang, jika memiliki skor total $33,33<x \leq 46,66$

27. Modal sosial tergolong rendah, jika memiliki skor total $20,00 \leq x \leq 33,33$.

28. Iming-iming dari calon investor terdiri dari norma usaha, format usaha, budaya usaha, keunggulan rencana komoditi yang ditawarkan, dan kekuatan modal (tidak diteliti diterima sebagai informasi sekunder dari calon investor).

29. Respon kemitraan merupakan suatu ukuran mudah atau sulitnya sikap patani, jika diajak dalam kegiatan agribisis kemitraan.

30. Respon masyarakat dalam pembentukan entitas agribisnis kemitraan dapat diukur melalui tanggapan masyarakat jika investor ingin membuka perkebunan, investor mengajak masyarakat bermitra sebagai petani plasma, investor memberikan manfaat (pendapatan, lapangan pekerjaan, pembangunan daerah, mensejahterahkan masyarakat), masyarkat bersedia merubah cara bertani sesuai dengan petunjuk investor, dan masyarakat bersedia mengikuti semua perjanjian sesuai dengan kesepakatan.

31. Agribisnis kemitraan akan mudah terjadi, jika respon masyarakat tergolong ke dalam kriteria sangat setuju dan setuju.

32. Agribisnis kemitraan akan sulit terjadi, jika respon masyarakat tergolong ke dalam kriteria tidak setuju dan kurang setuju.

33. Respon masyarakat dalam pembentukan entitas agribisnis kemitraan berkriteria sangat setuju, jika memiliki skor total $42,25<\mathrm{x} \leq 52,00$.

34. Respon masyarakat dalam pembentukan entitas agribisnis kemitraan berkriteria setuju, jika memiliki skor total $32,50<\mathrm{x} \leq 42,25$.

35. Respon masyarakat dalam pembentukan entitas agribisnis kemitraan berkriteria kurang setuju, jika memiliki skor total $22,75<\mathrm{x} \leq 32,50$

36. Respon masyarakat dalam pembentukan entitas agribisnis kemitraan berkriteria tidak setuju, jika memiliki skor total $13,00 \leq \mathrm{x} \leq 22,75$

\section{PELAKSANAAN PENELITIAN}

\section{A. Tempat dan Waktu}

Penentuan tempat penelitian dilakukan secara sengaja (purposive). Penelitian ini telah dilaksanakan di Desa Karang Endah dan Desa Tanjung Agung Kecamatan Lengkiti Kabupaten OKU. Pertimbangannya bahwa daerah-daerah yang memiliki prospek untuk dikembangkan agribisnis terletak di salah satu kecamatan yang ada di OKU, yakni Kecamatan Lengkiti, sesuai peraturan dan kebijakan pemerintah dalam Rencana Pembangunan Jangka
Panjang Daerah 2005-2025, UU Republik Indonesia Nomor 37 Tahun 2003 tentang Pembentukan Daerah Tingkat II dan Kotapraja di Provinsi Sumatera Selatan. Sedangkan, waktu Penelitian ini telah berlangsung dari bulan Agustus 2010 sampai dengan selesai.

\section{B. Metode Penelitian}

Metode yang digunakan dalam penelitian ini adalah metode survei. Metode survei merupakan studi ekstensif dan luas yang dipolakan untuk memperoleh informasi khusus (J.P.Chaplin, 1981 dalam Kartono, 1996), Metode survei digunakan karena permasalahan yang akan dibahas dalam skripsi ini didasarkan pada fakta-fakta dari gejala-gejala sosio-ekonomi, sehingga peneliti mencari keterangan-keterangan secara faktual di suatu daerah sebagai objek penelitian untuk menjawab fenomena sosio-ekonomi yang terjadi di kalangan masyarakat pada umumnya, dan dikalangan petani pada khususnya.

\section{Metode Penarikan Contoh}

Metode penarikan contoh yang digunakan adalah metode penarikan contoh acak sederhana (simple random sampling). Keuntungan menggunakan cara ini yakni tiap unit penelitian atau satuan elementer dari populasi mempunyai kesempatan yang sama untuk dipilih sebagai anggota sampel (Usman dan Akbar, 1995). Proporsi penarikan contoh untuk lebih jelasnya dapat dilihat pada Tabel 1 di bawah ini.

Tabel 1. Persentase Penarikan Contoh

\begin{tabular}{cccc}
\hline Desa Contoh & $\begin{array}{c}\text { Jumlah } \\
\text { Populasi } \\
(\mathrm{KK})\end{array}$ & $\begin{array}{c}\text { Jumlah Petani } \\
\text { Contoh } \\
(\mathrm{KK})\end{array}$ & $\begin{array}{c}\text { Persentase } \\
(\%)\end{array}$ \\
\hline Karang Endah & 590 & 30 & 5,08 \\
Tanjung Agung & 335 & 30 & 8,96 \\
\hline Jumlah & 925 & 60 & 6,49 \\
\hline \multirow{2}{*}{ Sumber: Kantor Kepala Desa Karang Endah dan Desa Tanjung Agung, 2014 }
\end{tabular}

\section{Metode Pengumpulan Data}

Data yang telah dikumpulkan di dalam penelitian ini berupa data primer dan data sekunder. Data primer berupa survei yang diperoleh dari wawancara langsung dengan petani tanaman karet dengan menggunakan kuisioner sebagai bahan pendekatan sosiologi pedesaan. Sedangkan data sekunder diperoleh dari Badan Pusat Statistik (BPS) Sumatera Selatan, Dinas Pertanian Tanaman Pangan dan Hortikultura Kabupaten Ogan Komering Ulu, Kantor Kepala Desa Karang Endah, Kantor Kepala Desa Tanjung Agung, Kantor Kecamatan Lengkiti, dan literatur yang ada hubungannya dengan penelitian. Pengumpulan data sekunder telah dilakukan pada bulan Agustus 2014 - November 2014, sedangkan pengambilan data primer telah dilakukan pada bulan Desember 2014 - Januari 2015. 


\section{E. Metode Pengolahan Data}

Pengolahan data untuk menjawab tujuan pertama yakni mengidentifikasi struktur pendapatan petani dalam pembentukan entitas agribisnis kemitraan dapat dihitung dengan menggunakan rumus :

$$
\begin{aligned}
\mathrm{TC}_{i} & =\mathrm{TFC}_{i}+\mathrm{TVC}_{i} \\
\mathrm{PNT}_{i} & =\mathrm{Y}_{i} \cdot \mathrm{Hy}_{i} \\
\mathrm{PDT}_{i} & =\sum_{k=1}^{i} \mathrm{PNT}-\sum_{k=1}^{i} \mathrm{TC} \\
\mathrm{PTK}_{i} & =\mathrm{PDT}_{i}+\mathrm{PLU}_{i}
\end{aligned}
$$

Keterangan :

$\mathrm{TC}_{i} \quad=$ Biaya total produksi (Rp/lg/tahun)

$\mathrm{TFC}_{i}=$ Biaya tetap total $(\mathrm{Rp} / \mathrm{lg} /$ tahun $)$

$\mathrm{TVC}_{i}=$ Biaya variabel total $(\mathrm{Rp} / \mathrm{lg} / \mathrm{tahun})$

$\mathrm{PNT}_{i}=$ Total penerimaan usahatani (Rp/lg/tahun)

$\mathrm{Y}_{i} \quad=$ Produksi (kg/tahun)

$\mathrm{Hy}_{i} \quad=$ Harga jual produksi $(\mathrm{Rp} / \mathrm{kg})$

$\mathrm{PTK}_{i}=$ Pendapatan Total Keluarga (Rp/tahun)

$\mathrm{PDT}_{i}=$ Pendapatan Usahatani (Rp/lg/tahun)

Pengolahan data untuk menjawab tujuan kedua yakni mengidentifikasi kondisi modal sosial masyarakat, maka indikator-indikator modal sosial dikelompokkan ke dalam interval kelas dengan pemberian skor 3 untuk kriteria tinggi, skor 2 untuk kriteria sedang dan skor 1 untuk kriteria rendah (Singarimbun dan Effendi, 1989):

Tabel 2. Interval kelas untuk modal sosial petani.

\begin{tabular}{cccc}
\hline $\begin{array}{c}\text { Nilai Interval Kelas } \\
\text { (Skor Total) }\end{array}$ & $\begin{array}{c}\text { Nilai Interval Kelas } \\
\text { (Per Indikator) }\end{array}$ & $\begin{array}{c}\text { Nilai Interval } \\
\text { Kelas } \\
\text { (Per Pertanyaan) }\end{array}$ & Kriteria \\
\hline $20,00 \leq \mathrm{x} \leq 33,33$ & $5,00 \leq \mathrm{x} \leq 8,33$ & $1,00 \leq \mathrm{x} \leq 1,67$ & Rendah \\
$33,33<\mathrm{x} \leq 46,66$ & $8,33<\mathrm{x} \leq 11,66$ & $1,67<\mathrm{x} \leq 2,33$ & Sedang \\
$46,66<\mathrm{x} \leq 60,00$ & $11,66<\mathrm{x} \leq 15,00$ & $2,33<\mathrm{x} \leq 3,00$ & Tinggi \\
\hline
\end{tabular}

Pengolahan data untuk menjawab tujuan ketiga menggunakan rumus NPV (Net Present Value) sebagai berikut :

$$
\begin{aligned}
& \text { NPV }=\text { PVB }- \text { PVC } \\
& \text { PVB }=\text { Penerimaan } \times \text { Df } \\
& \text { PVC }=\text { Biaya } \times \text { Df } \\
& \text { DF }=\frac{1}{(1+i)^{t}}
\end{aligned}
$$

Pengolahan data untuk menjawab tujuan keempat digunakan teknik penskalaan Likert, untuk pertanyaan positif dapat dikelompokkan ke dalam interval kelas dengan pemberian skor 4 untuk kriteria sangat setuju (SS), skor 3 untuk kriteria setuju (S), skor 2 untuk kriteria kurang setuju (KS) dan skor 1 untuk kriteria tidak setuju (TS) (Nazir, 1983 : 397).
Tabel 3. Interval kelas untuk respon agribisnis kemitraan.

\begin{tabular}{ccc}
\hline $\begin{array}{c}\text { Nilai Interval Kelas } \\
\text { (Skor Total) }\end{array}$ & $\begin{array}{c}\text { Nilai Interval Kelas } \\
\text { (Per Pertanyaan) }\end{array}$ & Kriteria \\
\hline $13,00 \leq \mathrm{x} \leq 22,75$ & $1,00 \leq \mathrm{x} \leq 1,75$ & Tidak Setuju \\
$22,75<\mathrm{x} \leq 32,50$ & $1,75<\mathrm{x} \leq 2,50$ & Kurang Setuju \\
$32,50<\mathrm{x} \leq 42,25$ & $2,50<\mathrm{x} \leq 3,25$ & Setuju \\
$42,25<\mathrm{x} \leq 52,00$ & $3,25<\mathrm{x} \leq 4,00$ & Sangat Setuju \\
\hline
\end{tabular}

\section{HASIL DAN PEMBAHASAN}

A. Struktur Pendapatan Total Petani Pra-Plasma sebagai Faktor Ekonomi dalam pembentukan Entitas Agribisnis Kemitraan

Struktur rata-rata pendapatan total masyarakat di Desa Karang Endah dan Desa Tanjung Agung 95,00 persen atau sebanyak 57 orang dari total petani contoh sebanyak 60 orang tergolong rendah. Hal ini dikarenakan lahan yang dimiliki petani belum digarap secara optimal. Selain itu rendahnya pendapatan ini disebabkan produktivitas tanaman-tanaman yang ada di kedua desa ini memang masing rendah. Rendahnya produktivitas ini karena keterbatan modal yang dimiliki petani, yang berdampak pada kurang intesifnya pemeliharaan seperti pemupukan. Produktivitas ini

\begin{tabular}{|c|c|c|}
\hline Pendapatan Total Petani (Rp/tahun) & $\begin{array}{l}\text { Jumlah } \\
\text { (orang) }\end{array}$ & $\begin{array}{c}\text { Persentase } \\
(\%)\end{array}$ \\
\hline \multicolumn{3}{|l|}{ Desa Karang Endah (Rp/tahun) } \\
\hline Rendah $(4.238 .539-51.144 .788)$ & 26 & 86,67 \\
\hline Sedang (51.144.789 - 98.051.037) & 2 & 6,67 \\
\hline Tinggi (98.051.038 - 144.957.286) & 2 & 6,67 \\
\hline Total & 30 & 100,00 \\
\hline \multicolumn{3}{|l|}{ Desa Tanjung Agung (Rp/tahun) } \\
\hline Rendah $(1.437 .780-76.317 .693)$ & 29 & 96,67 \\
\hline Sedang $(76.317 .694-151.197 .607)$ & 0 & 0,00 \\
\hline Tinggi $(151.197 .607-226.077 .520)$ & 1 & \\
\hline Total & 30 & 100,00 \\
\hline \multicolumn{3}{|l|}{ Rata-Rata (Rp/tahun) } \\
\hline Rendah (1.437.780 - 76.317.693) & 55 & 91,67 \\
\hline Sedang $(76.317 .694$ - 151.197.607) & 4 & 6,67 \\
\hline Tinggi (151.197.607 - 226.077.520) & 1 & 1,67 \\
\hline Total & 60 & 100,00 \\
\hline
\end{tabular}
menjadi rendah dikarenakan banyaknya gangguan hama seperti babi dan kera. Rendahnya pendapatan yang diterima petani ini menguntungkan pihak investor, sebab pada kondisi seperti ini petani lebih mudah untuk diajak bermitra.

Tabel 4.Struktur Rata-rata Pendapatan Masyarakat di Desa Karang Endah dan Desa Tanjung Agung.

Hal ini sesuai yang dikemukakan oleh Mubyarto (1989) dalam Asim (2001), akibat rendahnya pendapatan sekarang, dalam keaadaan yang paling ekstrim petani akan meninggalkan atau merubah usahanya ke bentuk usaha lain sehingga petani lebih mudah untuk diajak bermitra. Selain itu, Mardikanto (2009) mengungkapkan dalam pelaksanaanya, pihak investor memiliki beberapa keunggulan dalam hal ketersediaan sarana produksi, tersedianya teknologi budidaya serta jaminan pemasaran yang dimiliki. Keunggulan tersebut tidak dimiliki oleh petani, tetapi petani memiliki keunggulan dalam hal ketersediaan lahan, tenaga kerja, dan hasil produksi sebagai bahan baku bagi perusahaan. Bagi petani yang bermitra dengan adanya kerjasama kemitraan, maka biaya produksi dapat terpenuhi sehingga dapat berdampak positif terhadap pendapatan dan kesejahteraan petani. 


\section{B. Keadaan Modal Sosial Petani Sebagai Upaya Penujang Dalam Pembentukan Entitas Agribisnis Kemitraan}

Modal sosial dapat dijelaskan sebagai produk relasi manusia satu sama lain. Modal sosial menunjuk pada partisipasi dalam suatu jaringan, resiprositas, kepercayaan dan norma kepercayaan yang berpotensi pada produktivitas masyarakat. Maka dari itu, modal sosial tidak akan habis jika dipergunakan, melainkan semakin meningkat. Rusaknya modal sosial lebih sering disebabkan bukan karena dipakai, melainkan karena modal sosial tidak dipergunakan (Coleman 1988 dalam Yulianis dan Harfiati, 2008).

\section{Partisipasi Petani dalam Suatu Jaringan (Networks)}

Partisipasi petani di Desa Karang Endah dan Tanjung Agung adalah rendah, dengan rata-rata skor 6,37 dan rata-rata masing-masing skor di masingmasing desa 5,90 dan 6,83. Penyebabnya adalah para petani lebih memilih untuk berkebun daripada mengikuti suatu organisasi. Keterbatasan pendidikan yang dimiliki petani membuat petani merasa, kalau mengikuti suatu organisasi seperti koperasi atau kelompok tani tidak ada gunanya

Tabel 5. Rata-Rata Skor Partisipasi dalam Suatu Jaringan di Desa Karang Endah dan Desa Tanjung Agung, 2010

\begin{tabular}{lcccccc}
\hline \multirow{2}{*}{ Partisipasi Dalam Suatu Jaringan } & \multicolumn{3}{c}{ Desa } & \multicolumn{2}{c}{ Desa } & \multicolumn{2}{c}{ Rata-Rata } \\
\cline { 2 - 7 } & Skor & Kriteria & Skonjung Agung & Kriteria & Skor & Kriteria \\
\hline Jumlah organisasi yang diikuti & 1,07 & Rendah & 1,33 & Rendah & 1,20 & Rendah \\
Frekuensi kehadiran & 1,07 & Rendah & 1,33 & Rendah & 1,20 & Rendah \\
Memberikan informasi & 1,07 & Rendah & 1,13 & Rendah & 1,10 & Rendah \\
$\begin{array}{l}\text { Mengkoordinir orang lain dalam } \\
\text { kegiatan }\end{array}$ & 1,27 & Rendah & 1,43 & Rendah & 1,35 & Rendah \\
$\begin{array}{l}\text { Memberi ide/saran dalam tiap } \\
\text { permasalahan }\end{array}$ & 1,43 & Rendah & 1,60 & Rendah & 1,52 & Rendah \\
\hline \multicolumn{1}{c}{ Jumlah } & 5,90 & Rendah & 6,83 & Rendah & 6,37 & Rendah \\
\hline
\end{tabular}

Jika dilihat dari inidikator "partisipasi dalam suatu jaringan" yang tergolong rendah (nihil). Maka keadaan ini menyebabkan pembentukan entitas agribisnis kemitraan akan sulit terialisasikan, sebab keterbatasan petani ini menjadi kendala bagi pihak investor.

\section{Resiprositas (Resiprocity)}

Resiprositas yang ada di kedua desa ini tergolong sedang, dengan rata-rata skor 10,15. Gotong royong dalam usahatani yang ada di Desa Karang Endah tergolong tinggi dengan rata-rata skor 2,47. Sedangkan keadaan resiprositas yang ada di Desa Tanjung Agung dalam hal gotong royong dalam usahatani tergolong sedang dengan rata-rata skor 2,00. Hal ini dikarenakan di Desa Tanjung Agung kebanyakkan petani menggarap lahannya secara sendiri. Pelaksanaan jaga malam di Desa Karang Endah termasuk ke dalam kriteria rendah dengan skor 1,00 dan di Desa Tanjung Agung termasuk ke dalam kriteria sedang dengan skor rata-rata 2,07, sebab di Desa Karang Endah pelaksanaan jaga malam dilaksanakan secara intensif, jika sudah terjadi pencurian.
Tabel 6. Rata-Rata Skor Resiprositas di Desa Karang Endah dan Desa Tanjung Agung, 2010

\begin{tabular}{|c|c|c|c|c|c|c|}
\hline \multirow{2}{*}{ Resiprositas } & \multicolumn{2}{|c|}{$\begin{array}{c}\text { Desa } \\
\text { Karang Endah }\end{array}$} & \multicolumn{2}{|c|}{$\begin{array}{c}\text { Desa } \\
\text { Tanjung Agung }\end{array}$} & \multicolumn{2}{|c|}{ Rata-Rata } \\
\hline & Skor & Kriteria & Skor & Kriteria & Skor & Kriteria \\
\hline $\begin{array}{l}\text { Gotong royong membersihkan } \\
\text { siring }\end{array}$ & 2,47 & Tinggi & 2,00 & Sedang & 2,23 & Sedang \\
\hline Membantu penyelenggaraan acara & 2,43 & Tinggi & 2,57 & Tinggi & 2,50 & Tinggi \\
\hline $\begin{array}{l}\text { Membantu pembangunan rumah } \\
\text { petani }\end{array}$ & 2,17 & Sedang & 1,53 & Sedang & 1,85 & Sedang \\
\hline Melaksanakan jaga malam & 1,00 & Rendah & 2,07 & Sedang & 1,53 & Sedang \\
\hline $\begin{array}{l}\text { Membersihkan tempat ibadah } \\
\text { bersama }\end{array}$ & 2,17 & Sedang & 1,90 & Sedang & 2,03 & Sedang \\
\hline Jumlah & 10,23 & Sedang & 10,07 & Sedang & 10,15 & Sedang \\
\hline
\end{tabular}

Jika dilihat dari indikator "resiprositas", yang ada di Desa Karang Endah dan Desa Tanjung Agung ini, tergong ke dalam kriteria sedang (memadai). Maka potensi ini dapat menjadi penunjang dalam pembentukan entitas agribisnis kemitraan sehingga investasi agribisnis kemitraan ini akan mudah untuk direalisasikan.

\section{Kepercayaan (Trust)}

Pengukuran modal sosial dalam hal kepercayaan dapat dilihat dari tingkat kepercayaan petani terhadap petani lain, tingkat kepercayaan terhadap tokoh masyarakat, tingkat kepercayaan terhadap ketua oraganisai, tingkat kepercayaan terhdapat aparat pemerintah desa, dan tingkat kepercayaan terhadap pendatang (Robert dalam Mawardi, 2007). Kepercayaan di Desa Karang Endah dan Tanjung Agung secara keseluruhan tergolong sedang, dengan rata-rata skor 10,60 . Kepercayaan terhadap pendatang di Desa Desa Karang Endah lebih tinggi dari pada Desa Tanjung Agung dengan selisih skor 0,27. Hal ini dikarenakan masyarakat di Desa Karang Endah sudah banyak berasal dari daerah lain seperti dari daerah Jawa Tengah, Jawa Timur, dan Ambon. Selain itu, masyarakat terutama anak-anak petani di Desa Karang Endah sudah banyak yang merantau ke kota, baik itu untuk bekerja ataupun melanjutkan pendidikan tinggi seperti ke Palembang, Baturaja, Tanggerang, Jakarta dan akhirnya kembali lagi ke desa.

Tabel 7. Rata-Rata Skor Kepercayaan di Desa Karang Endah dan Desa Tanjung Agung, 2010

\begin{tabular}{lccccccc}
\hline \multirow{2}{*}{ Kepercayaan } & \multicolumn{3}{c}{ Desa } & \multicolumn{3}{c}{ Desa } & \multicolumn{2}{c}{ Rata-Rata } \\
\cline { 2 - 8 } & Skorang Endah & Kriteria & \multicolumn{2}{c}{ Skonjung Agung } & Kriteria & Skor & Kriteria \\
\hline $\begin{array}{l}\text { Kepercayaan terhadap petani } \\
\text { lain }\end{array}$ & 2,00 & Sedang & 1,90 & Sedang & 1,95 & Sedang \\
$\begin{array}{l}\text { Kepercayaan terhadap tokoh } \\
\text { masyarakat }\end{array}$ & 1,87 & Sedang & 2,07 & Sedang & 1,97 & Sedang \\
$\begin{array}{l}\text { Kepercayaan terhadap ketua } \\
\text { organisasi }\end{array}$ & 2,00 & Sedang & 2,03 & Sedang & 2,02 & Sedang \\
$\begin{array}{l}\text { Kepercayaan terhadap aparat } \\
\text { pemerintah }\end{array}$ & 2,33 & Sedang & 2,33 & Sedang & 2,33 & Sedang \\
$\begin{array}{l}\text { Kepercayan terhdap } \\
\text { pendatang }\end{array}$ & 2,47 & Tinggi & 2,20 & Sedang & 2,33 & Sedang \\
\hline \multicolumn{1}{c}{ Jumlah } & 10,67 & Sedang & 10,53 & Sedang & 10,60 & Sedang \\
\hline
\end{tabular}

Jika dilihat dari indikator "kepercayaan" yang tergolong sedang (memadai), maka pembentukan entitas agribisnis kemitraan akan mudah terjadi. Hal ini dikarenakan kondisi ini akan menguntungkan bagi pihak investor sebab kepercayaan merupakan produk utama dari modal sosial yang baik. 


\section{Norma Sosial (Norms)}

Keadaan norma sosial di Desa Karang Endah dan Desa Tanjung Agung tergolong ke dalam kriteria tinggi (memadai), dengan rata-rata skor 13,25. Akan tetapi, ketaatan terhadap aturan-aturan adat di Desa Karang Endah lebih rendah di bandingkan dengan Desa Tanjung Agung, sebab masyarakat di Desa Karang Endah sudah banyak merantau ke kota. Sehingga gaya hidup masyarakatnya hampir meniru gaya kehidupan masyarakat kota.

Tabel 8. Rata-Rata Skor Norma Sosial di Desa Karang Endah dan Desa Tanjung Agung, 2010

\begin{tabular}{|c|c|c|c|c|c|c|}
\hline \multirow{2}{*}{ Norma Sosial } & \multicolumn{2}{|c|}{$\begin{array}{c}\text { Desa } \\
\text { Karang Endah }\end{array}$} & \multicolumn{2}{|c|}{$\begin{array}{c}\text { Desa } \\
\text { Tanjung Agung }\end{array}$} & \multicolumn{2}{|c|}{ Rata-Rata } \\
\hline & Skor & Kriteria & Skor & Kriteria & Skor & Kriteria \\
\hline $\begin{array}{l}\text { Izin pertunangan dan } \\
\text { pernikahan }\end{array}$ & 2,83 & Tinggi & 2,87 & Tinggi & 2,85 & Tinggi \\
\hline Perjanjian bagi hasil & 2,40 & Tinggi & 2,90 & Tinggi & 2,65 & Tinggi \\
\hline $\begin{array}{l}\text { Sangsi pelanggaran norama } \\
\text { sosial }\end{array}$ & 2,70 & Tinggi & 2,77 & Tinggi & 2,73 & Tinggi \\
\hline $\begin{array}{l}\text { Pengambilan keputusan } \\
\text { secara musyawarah }\end{array}$ & 2,77 & Tinggi & 2,77 & Tinggi & 2,77 & Tinggi \\
\hline $\begin{array}{l}\text { Ketaatatan terhadap aturan } \\
\text { adat }\end{array}$ & 2,07 & Sedang & 2,43 & Tinggi & 2,25 & Sedang \\
\hline Jumlah & 12,77 & Tinggi & 13,73 & Tinggi & 13,25 & Tinggi \\
\hline
\end{tabular}

Jika dilihat dari indikator norma sosial, potensi ini tergolonng dalam kriteria tinggi (memadai). Maka pembentukan entitas agribisnis kemitraan akan mudah terjadi. Sesuai dengan teori, yang mengatakan jika suatu kelompok memberikan bobot tinggi pada norma sosial, maka kelompok masyarakat tersebut cenderung jauh lebih cepat berkembang maju dibandingkan pola kelompok masyarakat yang senantiasa menghindari keterusterangan, kompetisi, dan pencapaian (Ridell, 1997 dalam Yulianis dan Harfiati, 2008).

Secara keseluruhan dapat disimpulkan bahwa keadaan modal sosial di Desa Karang Endah dan Desa Tanjung Agung tergolong memadai, sehingga pembentukan entitas agribisnis akan mudah terjadi. Hal ini didukung oleh (Putnam, 1993; Fukuyama, 1995 dalam Yulianis dan Harfiati 2008) bahwa masyarakat yang memiliki modal sosial tinggi cenderung bekerja secara gotong royong, merasa aman untuk berbicara dan mampu mengatasi perbedaan-perbedaan, sehingga keadaan tersebut menyebabkan integrasi sosial yang tinggi dalam upaya pembentukan entitas agribisnis.

\section{Disparitas Pendapatan Usahatani Petani Pra- Plasma dengan Pendapatan Harapan Petani Pasca-Plasma serta Respon Masyarakat Dalam Pembentukan Entitas Agribisnis Kemitraan}

Berdasarkan nialai NPV dari tanaman karet di Desa Karang Endah dan Desa Tanjung Agung masingmasing yakni sebesar Rp. 815.279 dan Rp.2.653.770 per hektar per tahun. NPV dari tanaman kelapa sawit yang ditawarkan oleh pihak investor yakni sebesar Rp. 5.687.424 per hektar per tahun. Perbedaan NPV antara petani di Desa Karang Endah dan petani di Desa Tanjung Agung dikarenakan adanya perbedaan produksi dan biaya produksi yang dikeluarkan oleh petani. Secara finansial, tanaman kelapa sawit lebih menguntungkan daripada penanaman karet, sebab tanaman kelapa sawit memberikan total NPV lebih besar jika dibandingkan dengan total NPV karet. Kondisi ini dikarenakan perbedaan produksi dan biaya produksi. Rata-rata produksi tanaman kelapa sawit per tahunnya lebih tinggi daripada produksi tanaman karet. Hal ini dikarenakan cara penanaman dan perawatan kelapa sawit yang ditawarkan pihak investor dilakukan secara intensif serta menggunakan berbagai inovasi dan teknologi, sehingga produksi dihasilkan lebih tinggi.

Berdasarkan hasil kajian ini diketahui bahwa pembentukan entitas agribisnis akan mudah terjadi, hal ini dikarenakan pendapatan yang akan diterima masyarakat lebih besar dibandingkan dengan tanaman karet yang diusahakan saat ini. Merujuk dari Mubyarto (1989) dalam Asim (2001), akibat rendahnya pendapatan sekarang, dalam keaadaan yang paling ekstrim petani akan meninggalkan atau merubah usahanya ke bentuk usaha lain sehingga petani lebih mudah untuk diajak bermitra. Selain itu, ciri kehidupan masyarakat agraris di pedesaan nusantara yang sekarang ini sudah semakin konsumtif, sementara tidak semua unsur warga masyarakat mempunyai sumber pendapatan harian, mingguan serta bulanan yang terjamin. Ketergantungan petani pada sistem ijon masih sangat kental sehingga persoalan hutang dan ketidakmenentuan pendapatan akan selalu menjadi kendala, maka perkembangan investasi agribisnis akan mudah untuk terealisasikan di tengah perekonomian daerah yang struktur ekonominya tergolong rendah (Sjarkowi, 2010).

Rata-rata respon petani terhadap investor dalam pembentukan entitas agribisnis kemitraan di Desa Karang Endah dan Desa Tanjung Agung memiliki tanggapan setuju, dengan persentase 65 persen dari total petani contoh sebanyak 60 orang. Sedangkan, hanya sebesar 11,67 persen respon petani yang kurang setuju dalam pembentukan entitas agribisnis kemitraan. Ringkasan mengenai rata-rata respon petani dalam pembentukan entitas agribisnis kemitraan dapat dilihat pada Tabel 9.

Tabel 9. Persentase Rata-Rata Respon Masyarakat dalam Pembentukan Entitas Kemitraan Agribisnis di Desa Karang Endah dan Desa Tanjung Agung

\begin{tabular}{|c|c|c|c|c|c|c|}
\hline \multirow{2}{*}{$\begin{array}{l}\text { Respon Petani } \\
\text { Terhadap Calon } \\
\text { Investor }\end{array}$} & \multicolumn{2}{|c|}{$\begin{array}{c}\text { Desa } \\
\text { Karang Endah }\end{array}$} & \multicolumn{2}{|c|}{$\begin{array}{c}\text { Desa } \\
\text { Tanjung Agung } \\
\end{array}$} & \multicolumn{2}{|c|}{ Rata-Rata } \\
\hline & $\begin{array}{l}\text { Jumlah } \\
\text { (Orang) }\end{array}$ & $\begin{array}{l}\text { Persentase } \\
(\%)\end{array}$ & $\begin{array}{l}\text { Jumlah } \\
\text { (Orang) }\end{array}$ & $\begin{array}{l}\text { Persentase } \\
(\%)\end{array}$ & $\begin{array}{l}\text { Jumlah } \\
\text { (Orang) }\end{array}$ & $\begin{array}{c}\text { Persentase } \\
(\%)\end{array}$ \\
\hline Sangat Setu & 8 & 26,67 & 6 & 20,00 & 14 & 23,33 \\
\hline & 16 & & 23 & 76,6 & 39 & \\
\hline Kurang Setu & 6 & 20,6 & 1 & 3,33 & 7 & 11,67 \\
\hline Tidak Setuju & 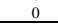 & 0,00 & 0 & 0,00 & 0 & 0,00 \\
\hline Jumlah & 30 & 100,00 & 30 & 100,00 & 60 & 100,00 \\
\hline
\end{tabular}

Keadaan seperti ini menunjukkan bahwa pembentukan entitas agribisnis akan mudah untuk terealisasikan. Hal ini dikarenakan dengan adanya pembukaan perkebunan kelapa sawit, petani mengharapkan pendapatan mereka akan meningkat dari sebelumnya. Selain itu, manfaat yang petani harapkan dari agribisnis kemitraan yakni perusahaan dapat memberikan lapangan pekerjaan baru, dan memajukan daerah mereka, serta memacu perkembangan tingkat pendidikan di kedua desa ini terutama untuk generasi-generasi penerus mereka, 
sebab menurut mereka pendidikan merupakan salah satu kendala untuk menentukan tingkat kesuksesan dan kesejahteraan mereka di masa yang akan datang. Hal ini mereka ungkapkan karena melihat realita lapangan seperti yang ada di Desa Peninjauan dan desa sekitar lainnya yang tergabung dalam PT.Mitra Ogan yang ternyata lebih makmur, baik dari segi pendapatan, lapangan pekerjaan, bahkan kemajuan daerah lebih baik setelah mereka bermitra. Akan tetapi, petani akan bermitra jika ada ganti rugi yang sesuai dengan tanaman tumbuh diatasnya, sebab jika tidak ada ganti rugi yang wajar maka para petani merasa mengalami kerugian atas tanaman-tanaman yang telah mereka kelola selama ini. Secara psikologis, petani di Desa Tanjung Agung pun bersedia merubah cara bertani mereka sesuai dengan yang dianjurkan oleh pihak investor, beda halnya dengan petani yang ada di Desa Karang Endah yang merasa kurang setuju untuk merubah cara bertani mereka, sebab sesuatu yang dilakukan mereka sekarang ini sudah menjadi kebiasan mereka secara turun-temurun.

Selain itu, faktor psikologis lainnya yaitu keengganan petani dalam menerima inovasi baru bahkan untuk menerapkan inovasi tersebut sangat sulit dilakukan petani, seperti yang dijelaskan dalam pembahasan partisipasi dalam suatu jaringan kondisi inilah yang menyebabkan banyak koperasi ataupun kelompok tani yang ada di Desa Karang Endah tidak bertahan lama. Jika bermitra petanipun bersedia mengikuti perjanjian sesuai dengan kesepakatan bersama, dan menjual hasil taninya kepada investor. Adanya sangsi yang telah menjadi tradisi di kedua desa ini, baik itu sangsi secara materil ataupun moril, membuat petani takut untuk melanggar suatu perjanjian. Akan tetapi secara teknis, petani yang ada di Desa Karang Endah dan Desa Tanjung Agung sebagian kurang setuju untuk mengganti tanaman karet menjadi kelapa sawit dan membagi lahan mereka kepada investor. Hal ini dikarenakan para petani merasa jika tanaman karet mereka diganti menjadi tanaman kelapa sawit, maka mereka akan kehilangan sumber mata pencaharian utamanya apalagi terdapat gastation period yang cukup panjang antara masa penanaman dan pemanenan. Padahal petani harus memenuhi kebutuhan rumah tangganya. Sedangkan, petani di Desa Karang Endah dan Desa Tanjung Agung kurang setuju untuk menyerahkan sebagian lahan mereka kepada pihak investor, sebab petani takut investor hanya akan merebut lahannya dengan modus agribisnis kemitraan. Padahal lahan yang ada saat ini merupakan warisan dari para leluhur mereka secara turun-temurun, dan jika kondisi itu memang terjadi artinya perekonomian yang ada di kedua desa ini akan semakin terjerumus dalam kemiskinan.

Berdasarkan hasil kajian sosio-ekonomi di Desa Karang Endah dan Desa Tanjung Agung. Maka secara matematis sederhana, dapat disimpulkan untuk Terima Ho point 0.1 bahwa apabila pendapatan usahatani petani pra-plasma lebih kecil daripada pendapatan harapan petani pasca plasma dan keadaan modal sosial memadai, maka pembentukan entitas agribisnis akan mudah terjadi. Menurut Sjarkowi (2004), berdasarkan studi empiris berdimensi sosekbud, langkah operasional yang dapat diterapkan sebagai syarat kehadiran solusi "win-win" serta tercapainya sinergi antara masyarakat, pemerintah dan investor. Maka jelas terapi sosekbud yang diperlukan adalah pemasyarakatan pola berusaha (tani) yang bersifat intensifikasi dan penciptaan nilai tambah yang bernuansa komersil, sebagaimana misalnya pola "agribisnis trisula" yang menjanjikan perolehan pendapatan harian, mingguan dan bulanan. Selain itu pemasyarakatan cara-cara memanfaatkan waktu ke arah kinerja produktif, dan hal ini mutlak harus dilakukan. Kinerja produtif itu sudah sepatutnya tepat guna (sesuai dengan budaya dan psikologis dan tingkat pendidikan masyarakat) dan tepat lokasi (sesuai dengan ketersedian dan ciri sumberdaya alami). Selain itu, untuk mensinergikan pemerintah, masyarakat dan investor maka peran dan fungsi pokok seperti yang digambarkan pada Gambar 3. dibawah ini harus dijadikan prinsip dasar yang tidak boleh dilanggar ataupun diabaikan, akan tetapi dapat dijabarkan lebih rinci sesuai dengan misi yang sedang akan diselenggarakan sehingga jelas "siapa berbuat apa".

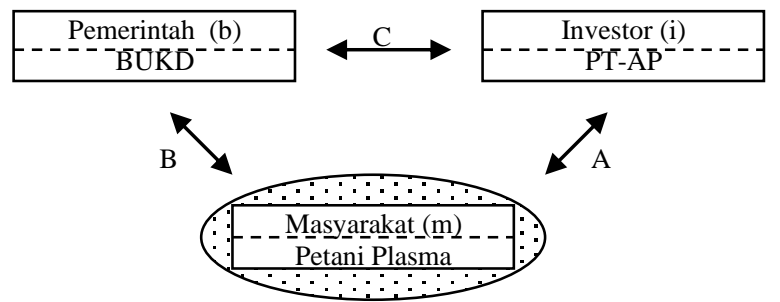

Keterangan :

A $\mathrm{i}-\mathrm{m}$ :Memberikan layanan manajemen standar dan memberikan pinjaman modal.

$\mathrm{A}_{\mathrm{m}-\mathrm{i}}$ :Memberikan komitmen penggunaan lahan menyertai pertanaman investor.

B b-m :Menjadi pengelola kepentingan dan peran-serta petani plasma.

B m-b :Menyalurkan aspirasi dan keluhan kepada lembaga untuk diperjuangkan.

$\mathrm{C}_{\text {b-i }}$ : Memusyawarakan dengan adil setiap hal ihwal yang datang dari salah satu pihak

$\mathrm{C}_{\mathrm{i}-\mathrm{b}}$ : Menyalurkan aspirasi perusahaan untuk disampaikan kepada plasma dan masyarakat

Berdasarkan hasil penelitian, kajian kepustakaan serta pemetaan kondisi sistem agribisnis kemitraan saat ini yang dikombinasikan dengan pemerintah, investor dan masyarakat. Maka, pemerintah dapat berperan sebagai pembina, pengatur dan pengawas beroperasinya mekanisme sistem agribisnis kemitraan. Pembinaan dilakukan oleh pemerintah sebagai upaya untuk memperkuat ikatan keterpaduan antarpelaku secara proposional, sekaligus memberikan sarana pelayanan yang mampu menjamin terselenggaranya integrasi sistem agribisnis kemitraan dengan kuat. Investor harus mempunyai dana sendiri yang cukup untuk membangun perkebunan, sebab mengandalkan kredit bank semata-mata untuk membangun kebunbaik itu kredit likuiditas apalagi kredit komersial-sudah 
tidak memungkinkan lagi. Selain itu, investor juga harus siap untuk memberdayakan masyarakat dan para karyawannya. Masyarakat harus bisa memberikan jaminan produksi yang tinggi dan keuntungan yang optimal bagi perusahaan kelak. Jangan sampai meningkatnya harga jual komoditi yang ditanam pada tingkat petani akan merangsang oknum-oknum tertentu untuk mencuri. Selain itu, terkait aspek lahan sebagai matriks tempat tanaman berada, maka komitmen mengenai pembebasan lahan harus sesuai dengan negoisasi yang diikuti dengan ketaatan terhadap hukum dan peraturan yang berlaku. Selanjutnya, sebagai penunjang keberhasilan agribisnis kemitraan, maka peran academician yaitu melakukan penelitian dan uji tuntas harus dilaksanakan secara mendalam.

\section{V.KESIMPULAN DAN SARAN}

\section{A. Kesimpulan}

Berdasarkan hasil penelitian ini, maka kesimpulan yang dapat dimbil adalah sebagai berikut :

1. Rata-rata struktur pendapatan total petani tergolong rendah, artinya pembentukan entitas agribsni kemitraan akan mudah terjadi.

2. Rata-rata keadaan modal sosial masyarakat tergolong memadai, hal ini menunjukkan bahwa pembentukan entitas agribisnis kemitraan akan mudah terjadi.

3. Pembentukan entitas agribisnis kemitraan akan mudah terjadi, karena rata-rata Pendapatan petani pra-plasma (karet) lebih kecil daripada pendapatan harapan petani pasca-plasma (kelapa sawit). Selain itu rata-rata respon masyarakat dalam pembentukan agribisnis kemitraan tergolong ke dalam kriteria setuju, artinya investasi agribisnis kemitraan akan mudah untuk terjadi.

\section{B. Saran}

Adapun saran yang dapat direkomendasikan berdasarkan hasil penelitian ini adalah sebagai berikut :

1. Pemerintah harus jelas memberikan kepastian formal tentang perizinan penyelenggaraan perkebunan kelapa sawit, dan peranan pemerintah sebagai fasilitator sebaiknya jangan terjebak dalam ambisi regulasi yang berlebihan, sehingga dalam pelaksanaanya seringkali tidak dapat menegakkan aturan yang dibuat oleh pemerintah itu sendiri.

2. Investor harus memiliki modal yang cukup besar, dan investor perlu menyentuh aspek pemberdayaaan masyarakat guna memberikan keharmonisan terhadap hubungan antara masyarakat dan perusahaan, sehingga terjalin kerjasama yang saling menguntungkan kedua belak pihak.

3. Masyarakat perlu mendukung agribisnis kemitraan yang dapat diwujudkan dalam hal ketersedian lahan dan faktor keamanan dari tindakan para pencuri.
4. Peneliti selanjutnya disarankan untuk melakukan kajian lebih mendalam terkait pengaruh variabelvariabel dimensi sosio-ekonomi, sosio budaya, dan sosio-psikologis dalam pembentukan entitas agribisnis kemitraan, sehingga dapat memberikan nilai tambah yang lebih besar bagi sistem agribisnis kemitraan secara keseluruhan.

\section{DAFTAR PUSTAKA}

Frasetiandy, D. 2009. Menakar Dampak Sosial Perkebunan Swait. Diakses pada 4 November 2010. (http://www.walhi.or.id, diakses 4 November 2010).

Hasbullah, J. 2006. Sosial Kapital : Menuju Keunggulan Budaya Manusia Indonesia. MRUnited Press. Jakarta.

Mardikanto, T. 2009. Membangun Pertanian Modern. LPP UNS dan UNS Press. Surakarta

Mawardi, M. 2007. Peranan Social Capital dalam Pemberdayaan Masyarakat (http://komunitas Wikispaces.com, diakses 13 september 2010).

Nazir, M.1983. Metode Penelitian. Ghalia Indonesia. Jakarta.

Pahan, I. 2008. Kelapa Sawit-Manaejemen Agribisnis Dari Hulu Hingga Hilir. Penebar Swadaya. Jakarta.

Ramadona, W. 2010. Hubungan Modal Sosial Petani dengan Pendapatan dan Tingkat Kesejahteraan Petani Karet di Kecamatan Tanjung Batu Kabupaten Ogan Ilir. Skripsi S1. (tidak dipublikasikan)

Siregar, 2009. Tingkat Kepuasan Petani MHR (Mengelola Hutan Rakyat) Acasia mangium (Studi Kasus Program MHR Unit III Gemawang) di Kawasan Hutan Tanaman Industri (HTI) PT. Musi Hutan Persada Kabupaten Muara Enim. Skripsi S1. (Tidak dipublikasikan).

Sjarkowi, F. 2004. Ekonomi Sumber Daya Alam dan Lingkungan. Baldad Grafiti Press. Palembang.

2010. Manajemen Pembangunan Agribisnis. Baldad Grafiti Press. Palembang 2010. Genuin Social Acceptance of Technical Innovation to Improve Profitability for Out Growers Associated with a Forestry Company in South Sumatera. Jurnal Agribisnis Kemitraan. Palembang.

2010. Peluang Kemitraan PT.Arthindo Pasific dan Masyarakat Lengkiti dan Sosoh Buay Rayap dalam Pembangunan Kelapa Sawit. Baturaja, November 2010..

Wirawan. 2003. Konsep Kemitraan. Disajikan pada Pertemuan Pemantapan Jejaring Kemitraan Dalam Menunjang Intensifikasi PPM-PL Tahun 2003. Cibogo-Jawa Barat, 29 Oktober s/d 1 November 2003.

Yulianis dan Harfiati. 2008. Modal Sosial dan Pengembangan Kelembagaan. IPB. Bogor. 
ISSN : 2598-0521

Zaelani, A. 2008. Manfaat Kemitraan Agribisnis Bagi Petani Mitra. Fakultas Pertanian IPB. Bogor. 